\title{
Molecular and serological diagnostic of leptospirosis: a review (2014-2020)
}

\author{
Diagnóstico molecular e sorológico da leptospirose: uma revisão (2014-2020) \\ Diagnóstico molecular y serológico de la leptospirosis: una revisión (2014-2020)
}

Received: 01/07/2022 | Reviewed: 01/13/2022 | Accept: 01/20/2022 | Published: 01/22/2022

Bárbara Couto Roloff Padilha

ORCID: https://orcid.org/0000-0003-3906-6851 Universidade Federal de Pelotas, Brasil E-mail: barbararoloff@gmail.com

Marcelle Moura Silveira

ORCID: https://orcid.org/0000-0001-5104-5039 Universidade Federal de Pelotas, Brasil E-mail: marcellemsilveira@gmail.com

Daiane Drawanz Hartwig

ORCID: https://orcid.org/0000-0003-3604-0832 Universidade Federal de Pelotas, Brasil E-mail: daianehartwig@gmail.com

\begin{abstract}
Leptospirosis is a zoonosis caused by pathogenic bacteria of the genus Leptospira. This disease affects several animals and humans. Symptoms of leptospirosis can range from mild to severe, may in some cases lead to death. For the diagnosis of leptospirosis, the microscopic agglutination test is considered the "gold standard"; however, it has limitations and studies are being conducted to develop alternative methods of screening and diagnosis of leptospirosis. Serological and immunochemical tests using Leptospira recombinant antigens in combination to molecular tests may be an alternative. In this study, we reported the advances achieved from 2014 until 2020 in controlling leptospirosis based on serological tests using recombinant antigens and molecular diagnosis.
\end{abstract}

Keywords: Serological tests; Immunochemical tests; Molecular diagnosis; Leptospirosis; Recombinant proteins.

\section{Resumo}

A leptospirose é uma zoonose causada por bactérias patogênicas do gênero Leptospira. Esta doença afeta vários animais e humanos. Os sintomas da leptospirose podem variar de leves a graves, podendo em alguns casos levar à morte. Para o diagnóstico de leptospirose, o teste de aglutinação microscópica é considerado o "padrão ouro"; entretanto, apresenta limitações e estudos estão sendo realizados para desenvolver métodos alternativos de rastreamento e diagnóstico da leptospirose. Testes sorológicos e imunoquímicos utilizando antígenos recombinantes de Leptospira, em combinação com testes moleculares, podem ser uma alternativa. Neste estudo, relatamos os avanços alcançados de 2014 a 2020 no controle da leptospirose com base em testes sorológicos com antígenos recombinantes e diagnóstico molecular.

Palavras-chave: Testes sorológicos; Testes imunoquímicos; Diagnóstico molecular; Leptospirose; Proteínas recombinantes.

\section{Resumen}

La leptospirosis es una zoonosis causada por bacterias patógenas del género Leptospira. Esta enfermedad afecta a varios animales y humanos. Los síntomas de la leptospirosis pueden variar de leves a graves y, en algunos casos, pueden provocar la muerte. Para el diagnóstico de la leptospirosis, la prueba de aglutinación microscópica se considera el "estándar de oro"; sin embargo, tiene limitaciones y se están realizando estudios para desarrollar métodos alternativos de detección y diagnóstico de la leptospirosis. Las pruebas serológicas e inmunoquímicas utilizando antígenos recombinantes de Leptospira en combinación con pruebas moleculares pueden ser una alternativa. En este estudio reportamos los avances logrados desde 2014 hasta 2020 en el control de la leptospirosis a partir de pruebas serológicas con antígenos recombinantes y diagnóstico molecular.

Palabras clave: Pruebas serológicas; Pruebas inmunoquímicas; Diagnóstico molecular; Leptospirosis; Proteínas recombinantes.

\section{Leptospira and leptospirosis}

Leptospirosis is a disease caused by pathogenic spirochetes of the genus Leptospira, family Leptospiraceae, and order Spirochaetales. These bacteria are spiral and helical in shape, having a length and width of $6-20 \mu \mathrm{m}$ and $0.1-0.2 \mu \mathrm{m}$, 
respectively (S. Faine, 1999). Furthermore, Leptospira spp. are classified into serovars according to the epitopes exposed on the surface in a mosaic of antigens, which can be proteins and lipopolysaccharides (LPS), and the specificity of epitopes is associated with sugar composition (Adler \& de la Pena Moctezuma, 2010). To date, the genus Leptospira contains 64 species divided into saprophytes, intermediates, and pathogenic (Guglielmini et al., 2019; Ko, Goarant, \& Picardeau, 2009; Philip et al., 2020). Regarding the serovars, approximately 300 have been reported, of which almost 270 are pathogenic (Gregoire et al., 2020; Guglielmini et al., 2019; Picardeau, 2017; Thibeaux et al., 2018).

Pathogenic Leptospira spp. can infect humans and animals. Moreover, the infection can be direct, i.e., through the urine of infected animals, or indirectly, i.e., through water or soil contaminated with the urine of infected animals (Jorge et al., 2018; S. Faine, 1999), despite this, however, the transmission of human-human leptospirosis remains unclear (Victoriano et al., 2009). Climatic conditions strongly influence the transmission of leptospires, which require hot and humid conditions for survival, bacteria can persist for weeks to months after excretion in water or moist soil (Mwachui, Crump, Hartskeerl, Zinsstag, \& Hattendorf, 2015; Sun, Liu, \& Yan, 2020).

Leptospirosis is an emerging zoonotic disease leading to more than one million of serious cases and 60,000 deaths each year worldwide, mainly in tropical countries (Grippi et al., 2020; Guglielmini et al., 2019; Lam, Low, \& Chee, 2020; Philip et al., 2020). In addition, leptospirosis is classified as a neglected disease of global distribution, which can affect a wide variety of domestic animals such as pets and those of economic interest, including dogs, cattle, and pigs, as well as wild animals, fish, and humans (Bharti et al., 2003; Mwachui et al., 2015; S. Faine, 1999; Vinetz, 2001). In humans, leptospirosis is considered a public health problem associated with a series of clinical signs affecting multiple organs, such as the liver, kidneys, lungs, and brain (Adler \& de la Pena Moctezuma, 2010; Gouveia et al., 2008; S. Faine, 1999). In animals, leptospirosis is associated with poor reproduction, abortions, premature births, and stillbirths, which lead to economic damage to the agricultural sector (Levett, 2001; Padilha, Simao, Oliveira, \& Hartwig, 2019; Petrakovsky, Bianchi, Fisun, NajeraAguilar, \& Pereira, 2014; S. Faine, 1999).

At present, the diagnosis of leptospirosis is based on both clinical examination and serological tests. Among all the tests used, the microscopic agglutination test (MAT) is considered the "gold standard" (Rajapakse et al., 2020). MAT test have as a principle to expose human or animal sera to a series of different strains of live leptospires and thus detects antibodies present in the sera samples (S. Faine, 1999). Although MAT is used as a reference method for the diagnosis of leptospirosis, it has several limitations, including low sensitivity in the acute phase of the disease (when antibodies are difficult to detect and there is a higher level of $\operatorname{IgM}$ ) and incapable of differentiating $\operatorname{IgM}$ from $\operatorname{IgG}$ antibodies (highly present in other phases of the disease) (McBride, Athanazio, Reis, \& Ko, 2005; Rajapakse, Rodrigo, Handunnetti, \& Fernando, 2015). In addition, many serological variants produce highly diverse strains, thus making it extremely difficult to identify them using this serological approach, resulting in several cross-reactions (Adler \& de la Pena Moctezuma, 2010). Also, MAT is an extremely laborious and expensive technique because of the need to maintain bacteria in cultivation (Caimi, Repetto, Varni, \& Ruybal, 2017).

Thus, alternative methods for screening and diagnosis of leptospirosis are being developed. Serological and immunochemical tests using Leptospira recombinant antigens, as well as molecular tests, have been described as alternatives for the diagnosis of leptospirosis.

\section{Study Criteria}

This review included all studies published in PubMed (http://www.ncbi.nlm.nih.gov/pubmed/) from 2014 until 2020 , which contained the following keywords: "Immunodiagnosis leptospirosis," "Serological diagnosis leptospirosis," "Detection Leptospira recombinant protein," "Diagnosis leptospirosis recombinant protein," "Immunodiagnosis leptospirosis recombinant protein," and "Molecular diagnosis leptospirosis," leading to 157, 103, 12, 32, 9, and 104 articles, respectively. The abstracts 
of these articles were analyzed, and all studies aimed at developing molecular and immunological diagnostic methods for leptospirosis were included in this review. Studies with other purposes were excluded. Thus, 67 articles were included in this review.

\section{Antigens of Leptospira spp. used in Diagnosis}

Several antigens of Leptospira spp. have been evaluated, many of them with potential for vaccine development (Conrad et al., 2017; da Cunha et al., 2019; Ghazali-Bina et al., 2019; Oliveira et al., 2019; Oliveira et al., 2018; Raja et al., 2018) or diagnosis (Alizadeh et al., 2014; Deneke et al., 2014; Nagalingam et al., 2015; Padilha et al., 2019; Shiokawa et al., 2016; Ye et al., 2014). As reported in other spirochetes, the Leptospira spp. codes more lipoproteins than other bacteria, containing approximately 145 genes for likely lipoproteins and outer membrane proteins (OMPs) (Setubal, Reis, Matsunaga, \& Haake, 2006; Viratyosin, Ingsriswang, Pacharawongsakda, \& Palittapongarnpim, 2008; Yang et al., 2006). Several proteins are already described and confirmed to be present on the surface of Leptospira spp. Among these, the well-known ones are the Lig, Loa22, LipL32, OmpL1, LenA, LenD, OmpL36, OmpL37, OmpL47, and OmpL54 (Ko et al., 2009; Lo, Cordwell, Bulach, \& Adler, 2009). Lipoproteins and OMPs are the main targets in the development of vaccine and diagnostic tests to leptospirosis control. All the cited antigens were frequently found in studies evaluating new diagnostic techniques (Table 1).

Table 1. Antigens evaluated in the development of diagnostic tests for leptospirosis.

\begin{tabular}{|c|c|c|c|}
\hline Antigen & Characteristic & Serovar used & Reference \\
\hline LipL32 & $\begin{array}{l}\text { Lipoprotein (outer } \\
\text { membrane) }\end{array}$ & L. interrogans serovar Copenhageni & $\begin{array}{l}\text { (Alizadeh et al., 2014; Shiokawa et } \\
\text { al., 2016; Ye et al., 2014) }\end{array}$ \\
\hline LigB & $\begin{array}{c}\text { Leptospiral } \\
\text { immunoglobulin-like protein } \\
\text { (outer membrane) }\end{array}$ & $\begin{array}{l}\text { L. interrogans serovar Pomona; } L \text {. } \\
\text { borgpetersenii serovar Hardjo }\end{array}$ & $\begin{array}{c}\text { (Deneke et al., 2014; Nagalingam et } \\
\text { al., 2015) }\end{array}$ \\
\hline LipL21 & $\begin{array}{l}\text { Lipoprotein (outer } \\
\text { membrane) }\end{array}$ & $\begin{array}{c}\text { L. interrogans serovar Pomona; } L . \\
\text { interrogans serovar Autumnalis }\end{array}$ & (Anita et al., 2016; Ye et al., 2014) \\
\hline Lsa63 & $\begin{array}{l}\text { Protein of adhesion (outer } \\
\text { membrane) }\end{array}$ & L. interrogans serovar Copenhageni & (Alizadeh et al., 2014) \\
\hline Loa22 & $\begin{array}{l}\text { Lipoprotein (outer } \\
\text { membrane) }\end{array}$ & L. interrogans serovar Pomona & (Ye et al., 2014) \\
\hline LigA & $\begin{array}{c}\text { Leptospiral } \\
\text { immunoglobulin-like protein } \\
\text { (outer membrane) }\end{array}$ & L. interrogans serovar Pomona & (Ye et al., 2014) \\
\hline ErpY-like & $\begin{array}{l}\text { Lipoprotein (outer } \\
\text { membrane)* }\end{array}$ & L. interrogans serovar Copenhageni & (Padilha et al., 2019) \\
\hline
\end{tabular}

* Location not yet described. Source: Authors (2021).

\section{Diagnosis of leptospirosis}

\subsection{Polymerase chain reaction}

Methods based on DNA amplification, such as polymerase chain reaction (PCR), are crucial tools for the detection of Leptospira spp. during the acute phase of the disease wherein antibodies are below the detection limit of the most serological tests (Ahmed, van der Linden, \& Hartskeerl, 2014; Denipitiya et al., 2016). The PCR is a fast, sensitive, and specific technique; however, it remains expensive (Courdurie et al., 2017; Waggoner \& Pinsky, 2016).

Several types of PCR have been used in the diagnosis of leptospirosis (Table 2). For example, conventional PCR (Gokmen, Soyal, Kalayci, Onlen, \& Koksal, 2016; Waggoner et al., 2015), real-time quantitative reverse transcription PCR 
(qRT-PCR) (Denipitiya et al., 2016; Nhan, Teissier, Roche, \& Musso, 2014; Waggoner et al., 2015; Waggoner \& Pinsky, 2016), real-time PCR with high resolution melting analysis (qRT-PCR-HRM) (Esteves et al., 2018), recombinase polymerase amplification (RPA) (Ahmed et al., 2014), PCR followed by restriction fragment length polymorphism (PCR-RFLP) (Gokmen et al., 2016), and assay loop-mediated isothermal amplification (Suwancharoen, Sittiwicheanwong, \& Wiratsudakul, 2016). The biological samples used in most of these studies were blood or its fractions (serum or plasma) (Ahmed et al., 2014; Denipitiya et al., 2016; Gokmen et al., 2016; Nhan et al., 2014; Waggoner et al., 2015) and urine (Esteves et al., 2018; Podgorsek et al., 2020; Suwancharoen et al., 2016).

Table 2. PCR-based methods used to detect Leptospira spp.

\begin{tabular}{|c|c|c|c|}
\hline DNA target & Variant of PCR & Host & Reference \\
\hline Part of gene lipL32 & RPA & Human & (Ahmed et al., 2014) \\
\hline Gene $\sec Y$ & qRT-PCR & Human & (Denipitiya et al., 2016) \\
\hline Genes $l f b l ; \sec Y$ & qRT-PCR-HRM & Human & (Esteves et al., 2018) \\
\hline Gene rrs; Gene lipL32; Gene ompll & $\begin{array}{c}\text { 16S rRNA-PCR followed by } \\
\text { 16S rRNA-PCR-RFLP; } \\
\text { LipL32-PCR; OmpL1-PCR }\end{array}$ & $\begin{array}{l}\text { Human and } \\
\text { bovine }\end{array}$ & (Gokmen et al., 2016) \\
\hline Gene $r r s$ & Taqman qPCR & Human & (Mohd Ali et al., 2018) \\
\hline Gene lipL32 & qRT-PCR & Human & (Nhan et al., 2014) \\
\hline Gene lipL32; Gene lipL41 & LAMP; qRT-PCR & Bovine & (Suwancharoen et al., 2016) \\
\hline Gene $r r s$ & Pathogenic qRT-PCR & Human & (Waggoner et al., 2015) \\
\hline Gene $16 S$; Gene lipL32 & $\begin{array}{l}\text { qRT-PCR; PCR } \\
\text { conventional }\end{array}$ & Human & (Waggoner \& Pinsky, 2016) \\
\hline Gene lipL32 & Multiplex PCR & Human & (Sea-Liang et al., 2019) \\
\hline Gene $16 S$ & Multiplex qPCR & $\begin{array}{l}\text { Wild and } \\
\text { domestic animals }\end{array}$ & $\begin{array}{c}\text { (Perez, Lanka, DeShambo, } \\
\text { Fredrickson, \& Maddox, 2020) }\end{array}$ \\
\hline Gene lipL32 & qRT-PCR & Human & (Podgorsek et al., 2020) \\
\hline Gene $r r s$ & PCR-nested PCR & Human & (Podgorsek et al., 2020) \\
\hline Gene $r r s$ & Duplex RT-PCR & Human & (Mohd Ali et al., 2019) \\
\hline
\end{tabular}

LAMP: loop-mediated isothermal amplification method; qRT-PCR-HRM: real-time PCR high resolution melting; qRT-PCR: real-time PCR; RFLP: restriction fragment lenght polymorphism; RPA: recombinase polymerase amplification. Source: Authors (2021).

Different PCR formats are developed to be used in both characterization and identification of Leptospira spp. in suspected samples. The molecular detection of Leptospira DNA is commonly based on marker genes such as $16 S$ rRNA, flaB, lipL32, lipL41, ligA, and ligB. The lipL32 gene encodes an outer membrane lipoprotein that is present in pathogenic Leptospira species but absent in nonpathogenic species (Haake et al., 2000; Chang et al., 2016). Therefore, a wide range of studies has based on the lipL32 gene (Gokmen et al., 2016; Waggoner et al., 2015) as the main test gene or as the method of comparison with the new test developed, as PCR, real-time loop-mediated isothermal amplification (RealAmp), real-time PCR, loopmediated isothermal amplification method (LAMP) and reverse-transcriptase PCR (Gokmen et al., 2016; Monica, Rathinasabapathi, \& Ramya, 2019; Nhan et al., 2014; Suwancharoen et al., 2016; Waggoner et al., 2015).

Techniques such as real-time PCR are promising, faster, highly sensitive, and require less product handling than conventional PCR (Denipitiya et al., 2016). In general, real-time PCR is performed on the basis of the 165 gene, which can be amplified only in the presence of pathogenic Leptospira DNA (Waggoner et al., 2015). However, it has been suggested that Leptospira spp. that are nonpathogenic, such as L. fainei, can cause infection; thus, excluding them from the detection panel can lead to detection errors (Mohd Ali et al., 2018). Therefore, Mohd Ali and colleagues (2017) developed and validated a panLeptospira real-time PCR using the rrs gene which can detect the presence of pathogenic and nonpathogenic Leptospira in the 
samples. In addition, to increase the accuracy of real-time PCR, Esteves and colleagues (2018) developed the qRT-PCR-HRM, which proved to be faster, more sensitive, specific, and cheaper, with $90 \%$ sensitivity and $97 \%$ specificity.

As an alternative to the high cost of implementing real-time PCR in the routine, the RPA technique (Ahmed et al., 2014) proved to be accurate, with sensitivity and specificity of $94.7 \%$ and $97.7 \%$, respectively. The 16SrRNA-PCR-RFLP (Gokmen et al., 2016) and RealAmp (Monica et al., 2019) techniques showed promising results, with an early and accurate diagnosis, which distinguished pathogenic and nonpathogenic species from Leptospira spp. Moreover, a novel multiplex PCR assay has been developed for identifying Orientia tsutsugamushi, Rickettsia typhi and Leptospira spp., causative agents of scrub typhus, murine typhus, and leptospirosis (Sea-Liang et al., 2019). The duplex TaqMan probe-based qPCR has been used for the simultaneous detection of Burkholderia pseudomallei and Leptospira spp. (Mohd Ali et al., 2019).

\subsection{Serological and immunochemical tests}

Serological tests are based on the detection of antibodies that are produced because of the stimulation of the host's humoral immune response generated by Leptospira spp. infection (S. Faine, 1999). The incubation period of bacteria in the development of leptospirosis can range between 2 to 30 days. The onset of symptoms typically begins with the appearance of agglutinating antibodies, which increases with disease progression (Lessa-Aquino et al., 2017). This type of response occurs against LPS and several proteins that are constitutively expressed or upregulated during infection (Adler \& de la Pena Moctezuma, 2010; Raja et al., 2018). However, IgM isotype antibodies appear approximately four days after symptom onset; this time varies according to the incubation period of the pathogen. The IgG isotype antibodies appear approximately 10 to 14 days, as they are more specific (Lessa-Aquino et al., 2017). Some serological diagnostic tests aim at an early result with the detection of IgM in the acute phase of the disease (Alizadeh et al., 2014; Courdurie et al., 2017; Kitashoji et al., 2015; Wynwood et al., 2016). Nonetheless, other tests aim for a more specific response, with the detection of IgG in the convalescent phase (Alizadeh et al., 2014; Anita et al., 2016; Brownlow et al., 2014; Nagalingam et al., 2015; Padilha et al., 2019; Shiokawa et al., 2016; Wynwood et al., 2016; Ye et al., 2014).

The LipL32 protein is the lipoprotein expressed in higher quantity in the outer membrane of leptospires, thus making it extremely immunogenic (Chang et al., 2016; Haake et al., 2000). In addition, LipL32 is conserved among pathogenic species and can be used as a distinctive marker for leptospirosis (Haake \& Matsunaga, 2002; Shiokawa et al., 2016). Another protein that has been widely used in the development of serological tests is LipL21, a crucial immunodominant protein expressed during infection (Nally, Whitelegge, Bassilian, Blanco, \& Lovett, 2007). Thus, these proteins are considered crucial targets in the serological diagnosis of leptospirosis (Table 3). 
Table 3. Serological tests for the diagnosis of leptospirosis.

\begin{tabular}{|c|c|c|c|}
\hline Protein target & Assay & Host & Reference \\
\hline rLsa63; rLipL32 & Indirect ELISA & Human & (Alizadeh et al., 2014) \\
\hline Unknown & LAT & Human & (Brownlow et al., 2014) \\
\hline rLigB & Indirect ELISA and LAT & Bovine & (Deneke et al., 2014) \\
\hline rLigA; Whole-cell & Capture ELISA & Human & (Kitashoji et al., 2015) \\
\hline rLipL21; rI-LipL21; Whole-cell & IgM ELISA and dotblot & Human & (Anita et al., 2016) \\
\hline rLigB & LAT & Bovine & (Nagalingam et al., 2015) \\
\hline rErpY-like & Indirect ELISA & Swine & (Padilha et al., 2019) \\
\hline rLipL32; rLigA; rArgC; rRecA; rLruC; rLruD & $\begin{array}{l}\text { Silver-enhanced nanogold } \\
\text { particle immunoassays }\end{array}$ & Human & (Raja et al., 2019) \\
\hline rLipL32 & Indirect ELISA & Rodents & (Shiokawa et al., 2016) \\
\hline Unknown & $\begin{array}{l}\text { Lateral flow based on specific } \\
\text { LPS immunochromatography }\end{array}$ & Human & (Vanithamani et al., 2015) \\
\hline Whole-cell & MIA & Human & (Wynwood et al., 2015) \\
\hline Whole-cell & MIA & Bovine & (Wynwood et al., 2016) \\
\hline rLipL21; rLoa22; rLipL32; rLigACon4-8 & Indirect ELISA & Canine & (Ye et al., 2014) \\
\hline rLipL32 & LAT & Human & $\begin{array}{c}\text { (Thongsukkaeng \& } \\
\text { Boonyom, 2018) }\end{array}$ \\
\hline
\end{tabular}

ELISA: enzyme-linked immunosorbent assay; LAT: latex agglutination test; LPS: lipopolysaccharides; MIA: microsphere immunoassay. Source: Authors (2021).

As shown in Table 3, most serological tests being developed are on the basis of enzyme-linked immunosorbent assay (ELISA) (Alizadeh et al., 2014; Courdurie et al., 2017; Deneke et al., 2014; Kitashoji et al., 2015; Padilha et al., 2019; Shiokawa et al., 2016; Ye et al., 2014) or in the latex agglutination test (LAT) (Brownlow et al., 2014; Deneke et al., 2014; Nagalingam et al., 2015). In addition, Wynwood and colleagues (2016) validated a microsphere immunoassay, which can simultaneously test many samples against a large number of serovars, as well as determine individual IgG and IgM titers. Overall, these factors would be extremely beneficial in laboratory diagnostics and in epidemiological studies of leptospirosis. Vanithamani and colleagues (2015) developed a lateral flow type assay based on LPS immunochromatography for the detection of IgM antibodies, which was sensitive and specific (>90\%). Furthermore, this test is simple and fast and allows diagnosis of serogroup in endemic regions.

Raja and colleagues (2019) used gold and silver nanoparticles associated with different proteins (some well-known and others are little studied) to develop a dot blot that was fast, reliable, and sensitive for the early detection of leptospirosis. Moreover, the lipL32 gene was described in an optimized DNA-based bioassay for the detection of Leptospira interrogans, which used gold nanoparticle-embedded carboxylated multiwalled carbon nanotubes electrode (Nagraik et al., 2019). Nanotechnology has enhanced our ability to diagnose, treat, and prevent infectious diseases. However, there are concerns to be addressed and studied with respect to its limitations, as their toxicity, their effect on the environment and effective cost of this technology.

\section{Final Considerations}

Controlling leptospirosis is still a challenge and, therefore, several studies have been evaluated with the aim to develop more sensitive and applicable diagnostic tests. Serological methods based on specific recombinant antigens are widely studied. However, molecular methods have been widely used because they can be effective as the acute phase of the disease anticipates treatment and prevents evolution and its complications. Considering the importance of leptospirosis both in public health and the agricultural sector encourages the scientific community to identify methods that aim to improve and facilitate 
the control of the disease. Therefore, several tests have been described to improve diagnostic accuracy, and several studies have shown promising results, bringing new perspectives for the diagnosis of leptospirosis.

\section{Acknowledgments}

This work was supported by the Coordenação de Aperfeiçoamento de Pessoal de Nível Superior - Brasil (CAPES, http://www.capes.gov.br/) - Grant 001 and Conselho Nacional de Desenvolvimento Científico e Tecnológico (CNPq, www.cnpq.br) - Grant 309716/2017-9.

\section{Conflict of interest}

The authors declare no conflict of interest. The founding sponsors had no role in the design of the study; in the collection, analyses, or interpretation of data; in the writing of the manuscript, and in the decision to publish the results.

\section{References}

Adler, B., \& de la Pena Moctezuma, A. (2010). Leptospira and leptospirosis. Vet Microbiol, 140(3-4), 287-296. doi: 10.1016/j.vetmic.2009.03.012

Ahmed, A., van der Linden, H., \& Hartskeerl, R. A. (2014). Development of a recombinase polymerase amplification assay for the detection of pathogenic Leptospira. Int J Environ Res Public Health, 11(5), 4953-4964. doi: 10.3390/ijerph110504953

Alizadeh, S. A., Abdolahpour, G., Pourmand, M. R., Naserpour, T., Najafipour, R., \& Eshraghi, S. S. (2014). Evaluation of New ELISA based on rLsa63 rLipL32 antigens for serodiagnosis of Human Leptospirosis. Iran J Microbiol, 6(3), 184-189.

Anita, K., Premlatha, M. M., Kanagavel, M., Akino Mercy, C. S., Raja, V., Shanmughapriya, S., \& Natarajaseenivasan, K. (2016). Evaluation of combined B cell specific N-terminal immunogenic domains of LipL21 for diagnosis of leptospirosis. Int J Biol Macromol, 91, 465-470. doi: 10.1016/j.ijbiomac.2016.05.109

Bharti, A. R., Nally, J. E., Ricaldi, J. N., Matthias, M. A., Diaz, M. M., Lovett, M. A., . . . Peru-United States Leptospirosis, C. (2003). Leptospirosis: a zoonotic disease of global importance. Lancet Infect Dis, 3(12), 757-771.

Brownlow, T., Kavanagh, O. V., Logan, E. F., Hartskeerl, R. A., Savage, R., Palmer, M. F., . . Ellis, W. A. (2014). 'Leptorapide' - a one-step assay for rapid diagnosis of human leptospirosis. Epidemiol Infect, 142(6), 1182-1187. doi: 10.1017/S0950268813002112

Caimi, K., Repetto, S. A., Varni, V., \& Ruybal, P. (2017). Leptospira species molecular epidemiology in the genomic era. Infect Genet Evol, 54, 478-485. doi: 10.1016/j.meegid.2017.08.013

Chang, M. Y., Cheng, Y. C., Hsu, S. H., Ma, T. L., Chou, L. F., Hsu, H. H., Tian, Y. C., Chen, Y. C., Sun, Y. J., Hung, C. C., Pan, R. L., \& Yang, C. W. (2016). Leptospiral outer membrane protein LipL32 induces inflammation and kidney injury in zebrafish larvae. Scientific reports, 6, 27838. https://doi.org/10.1038/srep27838

Conrad, N. L., Cruz McBride, F. W., Souza, J. D., Silveira, M. M., Felix, S., Mendonca, K. S., . . McBride, A. J. (2017). LigB subunit vaccine confers sterile immunity against challenge in the hamster model of leptospirosis. PLoS Negl Trop Dis, 11(3), e0005441. doi: 10.1371/journal.pntd.0005441

Courdurie, C., Le Govic, Y., Bourhy, P., Alexer, D., Pailla, K., Theodose, R., . . . Olive, C. (2017). Evaluation of different serological assays for early diagnosis of leptospirosis in Martinique (French West Indies). PLoS Negl Trop Dis, 11(6), e0005678. doi: 10.1371/journal.pntd.0005678

Cunha, C. E. P., Bettin, E. B., Bakry, A., Seixas Neto, A. C. P., Amaral, M. G., \& Dellagostin, O. A. (2019). Evaluation of different strategies to promote a protective immune response against leptospirosis using a recombinant LigA and LigB chimera. Vaccine, 37(13), 1844-1852. doi: 10.1016/j.vaccine.2019.02.010

Deneke, Y., Sabarinath, T., Gogia, N., Lalsiamthara, J., Viswas, K. N., \& Chaudhuri, P. (2014). Evaluation of recombinant LigB antigen-based indirect ELISA and latex agglutination test for the serodiagnosis of bovine leptospirosis in India. Mol Cell Probes, 28(4), 141-146. doi: 10.1016/j.mcp.2014.01.001

Denipitiya, D. T., Chandrasekharan, N. V., Abeyewickreme, W., Hartskeerl, C. M., Hartskeerl, R. A., Jiffrey, A. M., \& Hapugoda, M. D. (2016). Application of a real time Polymerase Chain Reaction (PCR) assay for the early diagnosis of human leptospirosis in Sri Lanka. Biologicals, 44(6), 497-502. doi: 10.1016/j.biologicals.2016.09.004

Esteves, L. M., Bulhoes, S. M., Branco, C. C., Carreira, T., Vieira, M. L., Gomes-Solecki, M., \& Mota-Vieira, L. (2018). Diagnosis of Human Leptospirosis in a Clinical Setting: Real-Time PCR High Resolution Melting Analysis for Detection of Leptospira at the Onset of Disease. Sci Rep, 8(1), 9213. doi: $10.1038 / \mathrm{s} 41598-018-27555-2$

Ghazali-Bina, M., Pourmand, M. R., Mirshafiey, A., Bakhtiari, R., Khaledi, A., Kazemian, H., . . Eshraghi, S. (2019). Vaccine potential of LenA and LcpA proteins of Leptospira interrogans in combination with Escherichia coli heat-labile enterotoxin, B subunit (LTB). Iran J Microbiol, 11 (1), 39-47.

Gokmen, T. G., Soyal, A., Kalayci, Y., Onlen, C., \& Koksal, F. (2016). Comparison of 16S rRNA-PCR-RFLP, LipL32-PCR and OmpL1-PCR methods in the diagnosis of leptospirosis. Rev Inst Med Trop Sao Paulo, 58, 64. doi: 10.1590/S1678-9946201658064 
Gouveia, E. L., Metcalfe, J., de Carvalho, A. L., Aires, T. S., Villasboas-Bisneto, J. C., Queirroz, A., . . Ko, A. I. (2008). Leptospirosis-associated severe pulmonary hemorrhagic syndrome, Salvador, Brazil. Emerg Infect Dis, 14(3), 505-508. doi: 10.3201/eid1403.071064

Gregoire, F., Bakinahe, R., Petitjean, T., Boarbi, S., Delooz, L., Fretin, D., . . Mori, M. (2020). Laboratory Diagnosis of Bovine Abortions Caused by NonMaintenance Pathogenic Leptospira spp.: Necropsy, Serology and Molecular Study Out of a Belgian Experience. Pathogens, 9(6). doi: $10.3390 /$ pathogens 9060413

Grippi, F., Giudice, E., Pietro, S. D., Sciacca, C., Santangelo, F., Galluzzo, P., . . Guercio, A. (2020). Leptospira interrogans Serogroup Sejroe Serovar Hardjo in Aborting Cows: Two Herd Cases in Sicily (Italy). J Vet Res, 64(1), 73-78. doi: 10.2478/jvetres-2020-0021

Guglielmini, J., Bourhy, P., Schiettekatte, O., Zinini, F., Brisse, S., \& Picardeau, M. (2019). Genus-wide Leptospira core genome multilocus sequence typing for strain taxonomy and global surveillance. PLoS Negl Trop Dis, 13(4), e0007374. doi: 10.1371/journal.pntd.0007374

Haake, D. A., Chao, G., Zuerner, R. L., Barnett, J. K., Barnett, D., Mazel, M., . . Bolin, C. A. (2000). The leptospiral major outer membrane protein LipL32 is a lipoprotein expressed during mammalian infection. Infect Immun, 68(4), 2276-2285. doi: 10.1128/iai.68.4.2276-2285.2000

Haake, D. A., \& Matsunaga, J. (2002). Characterization of the leptospiral outer membrane and description of three novel leptospiral membrane proteins. Infect Immun, 70(9), 4936-4945. doi: 10.1128/iai.70.9.4936-4945.2002

Jorge, S., Kremer, F. S., Oliveira, N. R., Navarro, G., Guimaraes, A. M., Sanchez, C. D., . . . Dellagostin, O. A. (2018). Whole-genome sequencing of Leptospira interrogans from southern Brazil: genetic features of a highly virulent strain. Mem Inst Oswaldo Cruz, 113(2), 80-86. doi: 10.1590/007402760170130

Kitashoji, E., Koizumi, N., Lacuesta, T. L., Usuda, D., Ribo, M. R., Tria, E. S., . . . Ariyoshi, K. (2015). Diagnostic Accuracy of Recombinant Immunoglobulin-like Protein A-Based IgM ELISA for the Early Diagnosis of Leptospirosis in the Philippines. PLoS Negl Trop Dis, 9(6), e0003879. doi: 10.1371/journal.pntd.0003879

Ko, A. I., Goarant, C., \& Picardeau, M. (2009). Leptospira: the dawn of the molecular genetics era for an emerging zoonotic pathogen. Nat Rev Microbiol, 7(10), 736-747. doi: 10.1038/nrmicro2208

Lam, J. Y., Low, G. K., \& Chee, H. Y. (2020). Diagnostic accuracy of genetic markers and nucleic acid techniques for the detection of Leptospira in clinical samples: A meta-analysis. PLoS Negl Trop Dis, 14(2), e0008074. doi: 10.1371/journal.pntd.0008074

Lessa-Aquino, C., Lindow, J. C., Randall, A., Wunder, E., Pablo, J., Nakajima, R., . . Felgner, P. L. (2017). Distinct antibody responses of patients with mild and severe leptospirosis determined by whole proteome microarray analysis. PLoS Negl Trop Dis, 11(1), e0005349. doi: 10.1371/journal.pntd.0005349

Levett, P. N. (2001). Leptospirosis. Clin Microbiol Rev, 14(2), 296-326. doi: 10.1128/CMR.14.2.296-326.2001

Lo, M., Cordwell, S. J., Bulach, D. M., \& Adler, B. (2009). Comparative transcriptional and translational analysis of leptospiral outer membrane protein expression in response to temperature. PLoS Negl Trop Dis, 3(12), e560. doi: 10.1371/journal.pntd.0000560

McBride, A. J., Athanazio, D. A., Reis, M. G., \& Ko, A. I. (2005). Leptospirosis. Curr Opin Infect Dis, 18(5), 376-386.

Mohd Ali, M. R., Lih Huey, L., Foo, P. C., Goay, Y. X., Ismail, A. S., Mustaffa, K. M. F., . . Yean Yean, C. (2019). Duplex TaqMan Hydrolysis Probe-Based Molecular Assay for Simultaneous Detection and Differentiation of Burkholderia pseudomallei and Leptospira spp. DNA. Biomed Res Int, $2019,9451791$. doi: $10.1155 / 2019 / 9451791$

Mohd Ali, M. R., Mohamad Safiee, A. W., Yusof, N. Y., Fauzi, M. H., Yean Yean, C., \& Ismail, N. (2017). Isolation of Leptospira kmetyi from residential areas of patients with leptospirosis in Kelantan, Malaysia. J Infect Public Health. doi: 10.1016/j.jiph.2017.12.008

Mohd Ali, M. R., Mohd Safee, A. W., Ismail, N. H., Abu Sapian, R., Mat Hussin, H., Ismail, N., \& Yean Yean, C. (2018). Development and validation of panLeptospira Taqman qPCR for the detection of Leptospira spp. in clinical specimens. Mol Cell Probes, 38, 1-6. doi: 10.1016/j.mcp.2018.03.001

Monica, N. I., Rathinasabapathi, P., \& Ramya, M. (2019). Development of real-time loop-mediated isothermal amplification (RealAmp) method for sensitive and rapid detection of pathogenic and nonpathogenic Leptospira. Lett Appl Microbiol, 68(2), 196-203. doi: 10.1111/lam.13108

Mwachui, M. A., Crump, L., Hartskeerl, R., Zinsstag, J., \& Hattendorf, J. (2015). Environmental and Behavioural Determinants of Leptospirosis Transmission: A Systematic Review. PLoS Negl Trop Dis, 9(9), e0003843. doi: 10.1371/journal.pntd.0003843

Nagalingam, M., Thirumalesh, S. R., Kalleshamurthy, T., Niharika, N., Balamurugan, V., Shome, R., . . . Rahman, H. (2015). Comparative evaluation of recombinant LigB protein and heat-killed antigen-based latex agglutination test with microscopic agglutination test for diagnosis of bovine leptospirosis. Trop Anim Health Prod, 47(7), 1329-1335. doi: 10.1007/s11250-015-0867-7

Nagraik, R., Kaushal, A., Gupta, S., Dhar, P., Sethi, S., \& Kumar, D. (2019). Optimized DNA-based bioassay for Leptospira interrogans detection: a novel platform for leptospirosis diagnosis. 3 Biotech, 9(7), 284. doi: 10.1007/s13205-019-1815-4

Nally, J. E., Whitelegge, J. P., Bassilian, S., Blanco, D. R., \& Lovett, M. A. (2007). Characterization of the outer membrane proteome of Leptospira interrogans expressed during acute lethal infection. Infect Immun, 75(2), 766-773. doi: 10.1128/IAI.00741-06

Nhan, T. X., Teissier, A., Roche, C., \& Musso, D. (2014). Sensitivity of real-time PCR performed on dried sera spotted on filter paper for diagnosis of leptospirosis. J Clin Microbiol, 52(8), 3075-3077. doi: 10.1128/JCM.00503-14

Oliveira, T. L., Rizzi, C., da Cunha, C. E. P., Dorneles, J., Seixas Neto, A. C. P., Amaral, M. G., . . Dellagostin, O. A. (2019). Recombinant BCG strains expressing chimeric proteins derived from Leptospira protect hamsters against leptospirosis. Vaccine, 37(6), 776-782. doi: 10.1016/j.vaccine.2018.12.050 
Oliveira, T. L., Schuch, R. A., Inda, G. R., Roloff, B. C., Neto, A., Amaral, M., . . Hartwig, D. D. (2018). LemA and Erp Y-like recombinant proteins from Leptospira interrogans protect hamsters from challenge using AddaVax as adjuvant. Vaccine, 36(19), 2574-2580. doi: 10.1016/j.vaccine.2018.03.078

Padilha, B. C. R., Simao, H. Q., Oliveira, T. L., \& Hartwig, D. D. (2019). The use of ErpY-like recombinant protein from Leptospira interrogans in the development of an immunodiagnostic test for swine leptospirosis. Acta Trop, 193, 31-34. doi: 10.1016/j.actatropica.2019.01.027

Perez, L. J., Lanka, S., DeShambo, V. J., Fredrickson, R. L., \& Maddox, C. W. (2020). A Validated Multiplex Real-Time PCR Assay for the Diagnosis of Infectious Leptospira spp.: A Novel Assay for the Detection and Differentiation of Strains From Both Pathogenic Groups I and II. Front Microbiol, 11, 457. doi: $10.3389 /$ fmicb.2020.00457

Petrakovsky, J., Bianchi, A., Fisun, H., Najera-Aguilar, P., \& Pereira, M. M. (2014). Animal leptospirosis in Latin America and the Caribbean countries: reported outbreaks and literature review (2002-2014). Int J Environ Res Public Health, 11(10), 10770-10789. doi: 10.3390/ijerph111010770

Philip, N., Bahtiar Affendy, N., Ramli, S. N. A., Arif, M., Raja, P., Nagandran, E., . . Neela, V. K. (2020). Leptospira interrogans and Leptospira kirschneri are the dominant Leptospira species causing human leptospirosis in Central Malaysia. PLoS Negl Trop Dis, 14(3), e0008197. doi: 10.1371/journal.pntd.0008197

Picardeau, M. (2017). Virulence of the zoonotic agent of leptospirosis: still terra incognita? Nat Rev Microbiol, 15(5), 297-307. doi: 10.1038/nrmicro.2017.5

Podgorsek, D., Ruzic-Sabljic, E., Logar, M., Pavlovic, A., Remec, T., Baklan, Z., . . Cerar, T. (2020). Evaluation of real-time PCR targeting the lipL32 gene for diagnosis of Leptospira infection. BMC Microbiol, 20(1), 59. doi: 10.1186/s12866-020-01744-4

Raja, V., Prasad, M., Bothammal, P., Saranya, P., Sumaiya, K., Akino Mercy, C. S., \& Natarajaseenivasan, K. (2019). Silver enhanced nano-gold dot blot immunoassay for leptospirosis. J Microbiol Methods, 156, 20-22. doi: 10.1016/j.mimet.2018.11.021

Raja, V., Sobana, S., Mercy, C. S. A., Cotto, B., Bora, D. P., \& Natarajaseenivasan, K. (2018). Heterologous DNA prime-protein boost immunization with RecA and FliD offers cross-clade protection against leptospiral infection. Sci Rep, 8(1), 6447. doi: 10.1038/s41598-018-24674-8

Rajapakse, S., Rodrigo, C., Handunnetti, S. M., \& Fernando, S. D. (2015). Current immunological and molecular tools for leptospirosis: diagnostics, vaccine design, and biomarkers for predicting severity. Ann Clin Microbiol Antimicrob, 14, 2. doi: 10.1186/s12941-014-0060-2

Rajapakse, S., Weeratunga, P. N., Balaji, K., Ramchandani, K. C., de Silva, U. S., Ranasinghe, S. A., . . . Fernando, S. D. (2020). Seroprevalence of leptospirosis in an endemic mixed urban and semi-urban setting-A community-based study in the district of Colombo, Sri Lanka. PLoS Negl Trop Dis, 14(5), e0008309. doi: 10.1371/journal.pntd.0008309

S. Faine, B. A., C. Bolin, P. Perolat. (1999). Leptospira and Leptospirosis.

Sea-Liang, N., Sereemaspun, A., Patarakul, K., Gaywee, J., Rodkvamtook, W., Srisawat, N., . . Hemachudha, T. (2019). Development of multiplex PCR for neglected infectious diseases. PLoS Negl Trop Dis, 13(7), e0007440. doi: 10.1371/journal.pntd.0007440

Setubal, J. C., Reis, M., Matsunaga, J., \& Haake, D. A. (2006). Lipoprotein computational prediction in spirochaetal genomes. Microbiology, 152(Pt 1), 113121. doi: $10.1099 /$ mic.0.28317-0

Shiokawa, K., Gamage, C. D., Koizumi, N., Sakoda, Y., Shimizu, K., Tsuda, Y., . . . Arikawa, J. (2016). Evaluation of truncated LipL32 expressed by Escherichia coli and Pichia pastoris for serodiagnosis of Leptospira infection in rodents. J Vet Med Sci, 78(2), 221-230. doi: 10.1292/jvms.15-0325

Sun, A. H., Liu, X. X., \& Yan, J. (2020). Leptospirosis is an invasive infectious and systemic inflammatory disease. Biomed J, 43(1), 24-31. doi: 10.1016/j.bj.2019.12.002

Suwancharoen, D., Sittiwicheanwong, B., \& Wiratsudakul, A. (2016). Evaluation of loop-mediated isothermal amplification method (LAMP) for pathogenic Leptospira spp. detection with leptospires isolation and real-time PCR. J Vet Med Sci, 78(8), 1299-1302. doi: 10.1292/jvms.15-0702

Thibeaux, R., Iraola, G., Ferres, I., Bierque, E., Girault, D., Soupe-Gilbert, M. E., . . Goarant, C. (2018). Deciphering the unexplored Leptospira diversity from soils uncovers genomic evolution to virulence. Microb Genom, 4(1). doi: 10.1099/mgen.0.000144

Thongsukkaeng, K., \& Boonyom, R. (2018). Development and evaluation of latex agglutination test coating with recombinant antigen, LipL32 for serodiagnosis of human leptospirosis. J Genet Eng Biotechnol, 16(2), 441-446. doi: 10.1016/j.jgeb.2018.10.002

Vanithamani, S., Shanmughapriya, S., Narayanan, R., Raja, V., Kanagavel, M., Sivasankari, K., \& Natarajaseenivasan, K. (2015). Lipopolysaccharide Specific Immunochromatography Based Lateral Flow Assay for Serogroup Specific Diagnosis of Leptospirosis in India. PLoS One, 10(9), e0137130. doi: 10.1371/journal.pone.0137130

Victoriano, A. F., Smythe, L. D., Gloriani-Barzaga, N., Cavinta, L. L., Kasai, T., Limpakarnjanarat, K., . . Adler, B. (2009). Leptospirosis in the Asia Pacific region. BMC Infect Dis, 9, 147. doi: 10.1186/1471-2334-9-147

Vinetz, J. M. (2001). Leptospirosis. Curr Opin Infect Dis, 14(5), 527-538. doi: 10.1097/00001432-200110000-00005

Viratyosin, W., Ingsriswang, S., Pacharawongsakda, E., \& Palittapongarnpim, P. (2008). Genome-wide subcellular localization of putative outer membrane and extracellular proteins in Leptospira interrogans serovar Lai genome using bioinformatics approaches. BMC Genomics, 9, 181. doi: 10.1186/1471-2164-9181

Waggoner, J. J., Balassiano, I., Mohamed-Hadley, A., Vital-Brazil, J. M., Sahoo, M. K., \& Pinsky, B. A. (2015). Reverse-Transcriptase PCR Detection of Leptospira: Absence of Agreement with Single-Specimen Microscopic Agglutination Testing. PLoS One, 10(7), e0132988. doi: 10.1371/journal.pone.0132988 
Research, Society and Development, v. 11, n. 2, e19511225471, 2022

(CC BY 4.0) | ISSN 2525-3409 | DOI: http://dx.doi.org/10.33448/rsd-v11i2.25471

Waggoner, J. J., \& Pinsky, B. A. (2016). Molecular diagnostics for human leptospirosis. Curr Opin Infect Dis, 29(5), 440-445. doi: 10.1097/QCO.0000000000000295

Wynwood, S. J., Burns, M. A., Graham, G. C., Weier, S. L., McKay, D. B., \& Craig, S. B. (2015). Validation of a microsphere immunoassay for serological leptospirosis diagnosis in human serum by comparison to the current gold standard. PLoS Negl Trop Dis, 9(3), e0003636. doi: 10.1371/journal.pntd.0003636

Wynwood, S. J., Burns, M. A., Graham, G. C., Weier, S. L., McKay, D. B., \& Craig, S. B. (2016). Serological diagnosis of Leptospirosis in bovine serum samples using a microsphere immunoassay. Vet Rec Open, 3(1), e000148. doi: 10.1136/vetreco-2015-000148

Yang, H. L., Zhu, Y. Z., Qin, J. H., He, P., Jiang, X. C., Zhao, G. P., \& Guo, X. K. (2006). In silico and microarray-based genomic approaches to identifying potential vaccine candidates against Leptospira interrogans. BMC Genomics, 7, 293. doi: 10.1186/1471-2164-7-293

Ye, C., Yan, W., Xiang, H., He, H., Yang, M., Ijaz, M., . . Chang, Y. F. (2014). Recombinant antigens rLipL21, rLoa22, rLipL32 and rLigACon4-8 for serological diagnosis of leptospirosis by enzyme-linked immunosorbent assays in dogs. PLoS One, 9(12), e111367. doi: 10.1371/journal.pone.0111367 